\title{
Health Impacts of Coal Combustion
}

\section{Energy from Coal Combustion}

Coal, a combustible rock rich in carbon, is a crucial component of the energy mix that fuels our society. About 52 percent of the electricity produced in the United States comes from combustion of coal. In addition, coal is the fuel of choice for most heat-intensive industrial processes, such as production of steel, aluminum, concrete, and wallboard.

Many countries are even more reliant on coal for their energy needs than is the United States. For example, more than 70 percent of the electricity generated in China, India, Australia, Greece, and the Czech Republic comes from coal. Poland and South Africa rely on coal for about 95 percent of their electricity.

\section{Environmental Impacts of Coal Combustion}

The value of coal is partially offset by the environmental impacts of coal combustion. Some of these impacts have indirect or direct consequences on human health. An indirect consequence would be the possible human health effects of climate change caused by emission of greenhouse gases, such as carbon dioxide, from combustion of coal and other fossil fuels (fig. 1). This highly controversial topic will require additional time and information to resolve.

Severe health problems attributed to air pollution caused by coal combustion were recorded as long ago as the tenth century in London. Regional and local air pollution episodes occurred in the United States until the middle of the 20th century.

\section{Modern Coal-Burning Utilities Do Not Cause Health Problems}

The principal pollutants generated by coal combustion that can cause health problems are particulates, sulfur and nitrogen oxides, trace elements (including arsenic, fluorine, selenium, and the radionuclides uranium and thorium), and

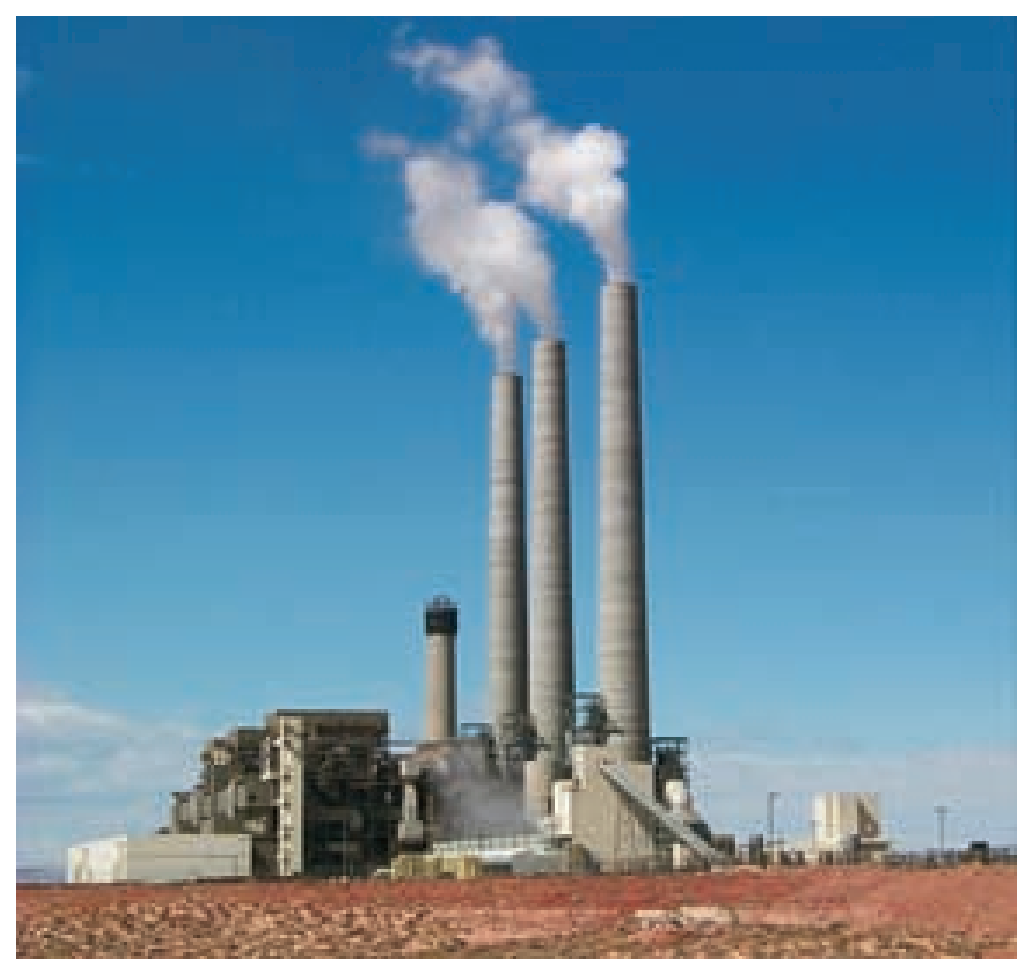

Figure 1. Powerplants burn coal to produce electricity. The emissions are largely steam (water vapor) and carbon dioxide and do not present any direct health hazard. Photograph by Jason Willett, USGS.

organic compounds generated by incomplete coal combustion. Recently, the U.S. Environmental Protection Agency (EPA) conducted a detailed study of possible health impacts from exposure to emissions of about 20 potentially toxic substances from coal-burning electric utilities. The EPA used U.S. Geological Survey (USGS) information on U.S. coal quality to assess the potential health impacts of about 14 potentially toxic trace elements that may be mobilized by coal combustion. The EPA concluded that, with the possible exception of mercury, there is no compelling evidence to indicate that emissions from U.S. coal-burning electric utilities cause human health problems. The absence of detectable health problems is in part due to the fact that the coals burned in the United States generally contain low to modest concentrations of potentially toxic trace elements and sulfur and that many coal-burning utilities use sophisticated pollution-control systems that efficiently reduce the emission of hazardous elements.

\section{Improper Use of Coal or the Use of Poor-Quality Coal May Cause Health Problems}

In many developing countries, emissions from coal use can present serious human health problems, especially in homes where coal is used for heating and cooking. The problems arise because the coals are generally mined locally with little regard to their composition and the coals are commonly burned in poorly vented or unvented stoves, directly exposing residents to the emissions. In China alone, several hundred million people commonly burn raw coal in unvented stoves that permeate their homes with high levels of toxic metals and organic compounds. 


\section{Arsenic}

At least 3,000 people in Guizhou Province in southwestern China are suffering from severe arsenic poisoning (fig. 2). The primary source of the arsenic appears to be consumption of chili peppers dried over fires fueled with high-arsenic coal. Coals in the region contain up to 35,000 parts per million (ppm) arsenic. Chili peppers dried over these high-arsenic coal fires adsorb 500 ppm arsenic on average (Finkelman and others, 1999).

When a powerplant in Czechoslovakia was burning high-arsenic coal, a study of the children living in the vicinity indicated that they suffered a greater incidence of hearing loss than children living far away (Bencko and Symon, 1977).

\section{Fluorine and Selenium}

More than 10 million people in Guizhou Province and surrounding areas suffer from dental fluorosis and skeletal fluorosis (a crippling bone disease). The excess fluorine is due to eating corn dried over burning briquettes made from high-fluorine coals and high-fluorine clay binders. There is evidence that selenium derived from coal combustion in China caused human selenosis.

\section{Uranium and Thorium}

Radioactivity from uranium and thorium in coal has been cited as a potential health problem. However, there is no evidence to date that radioactivity from coal or coal-combustion products has caused any human health problems.

\section{Ground Water, Coal, and Kidney Disease}

In a very unusual situation in the former Yugoslavia, Romania, and Bulgaria, the coals are believed to contribute to a serious kidney disease known as Balkan endemic nephropathy. Tatu and others (1998) suggested that well water in contact with lignite (low-grade coal) aquifers may extract organic compounds from the coal. These organic compounds may accelerate the degradation of kidney tissue and cause related cancers.

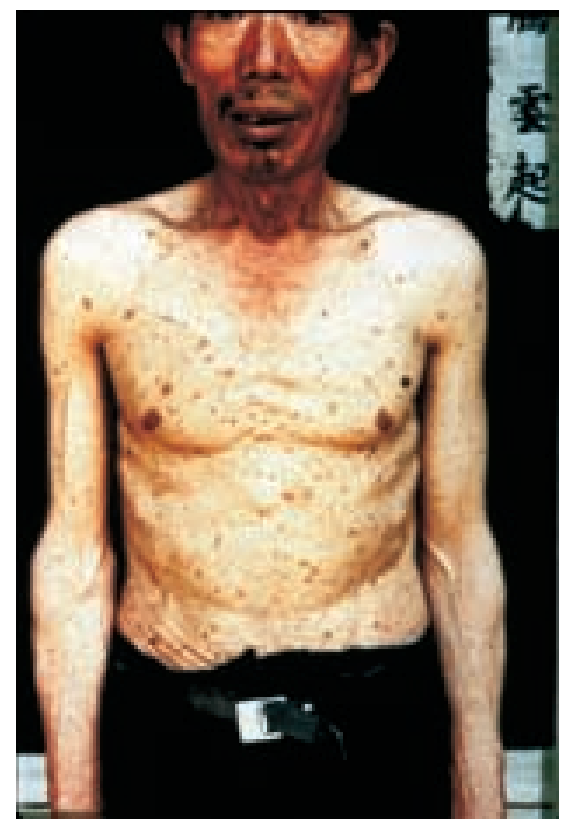

Figure 2. Skin lesions caused by exposure to arsenic mobilized by coal combustion in China. Photograph courtesy of Baoshon Zheng, Institute of Geochemistry, Guiyang, China.

\section{Organic Compounds}

Polycyclic aromatic hydrocarbons (PAH's) released during unvented coal combustion in homes in China have been cited as the primary cause for the highly elevated incidence of lung cancer. The PAH levels in homes burning "smokey" coal are so high that the resulting lung cancer mortality rate is five times the national average of China (Mumford and others, 1987).

\section{USGS Coal-Quality Studies}

The USGS, in cooperation with State geological surveys, has been collecting coal-quality data for the United States for more than 20 years to create a comprehensive national coal data base. Data are available on the Internet at http://energy.er.usgs.gov/products/ databases/CoalQual/index.htm.

Now the USGS, in cooperation with more than 40 coal-producing countries, is developing an international coal-quality data base (World Coal Quality Inventory: WoCQI). The data can be used to assess global pollution from coal combustion and to help the host countries evaluate regional and local environmental and health impacts.

\section{Conclusions}

Emissions from utility coal combustion in the United States do not present a threat to human health. Nevertheless, domestic coal use in developing countries has caused serious human health problems. Coal scientists and technologists are ideally positioned to help medical and public health specialists improve public health in these countries. The USGS is working with scientists and medical professionals in several developing countries to provide analytical data, technical training, and modern technology such as digital maps. The information being generated may help to minimize the health impacts of coal use and help to avoid future problems.

\section{References}

Bencko, V., and Symon, K., 1977, Health aspects of burning coal with a high arsenic content. II. Hearing aspects of burning coal with a high arsenic content: Environmental Research, v. 13, p. 386-395.

Finkelman, R.B., Belkin, H.E., and Zheng, B., 1999, Health impacts of domestic coal use in China: [U.S.] National Academy of Science Proceedings, v. 96, p. 3427-3431.

Mumford, J.L., and others, 1987, Lung cancer and indoor air pollution in Xuan Wei, China: Science, v. 235, p. 217-220.

Tatu, C.A., Orem, W.H., Finkelman, R.B., and Feder, G.L., 1998, The etiology of Balkan endemic nephropathy; Still more questions than answers: Environmental Health Perspectives, v. 106, no. 11, p. 689-700.

For more information, please contact:

Robert B. Finkelman

U.S. Geological Survey

National Center, Mail Stop 956

Reston, VA 20192

E-mail: rbf@usgs.gov

Telephone: 703-648-6412

Fax: 703-648-6419 